\title{
Tradições de agressividade, disciplina e sistema de internação de jovens em Alagoas $(1980-2015)^{1}$
}

Fernando Rodrigues*

\begin{abstract}
Resumo
Propõe-se uma análise do curso de tradições de agressividade e disciplina expresso no perfil de monitores do sistema de internação alagoano nas últimas quatro décadas. Destaca-se a relação entre aspectos da distribuição de poder político - policial e eleitoral - e a reprodução de instabilidades administrativas no sistema socioeducativo, repercutindo na padronização de práticas e ideais disciplinares entre monitores. Aborda-se o recente movimento de intensificação do encarceramento juvenil em Alagoas e a oscilação na direção da gestão disciplinar das unidades, ora pendendo para uma perspectiva de monitores socioeducadores ora tendendo para uma orientação de agente penitenciário.
\end{abstract}

\section{Palavras-chave}

Agressividade. Disciplina. Sistema de Internação de Adolescents.

\section{Abstract}

It is proposed an analysis of the course of aggression and discipline traditions expressed in the security agents profile from alagoasian juveniles houses of custody in the last four decades.

\footnotetext{
${ }^{1}$ Este artigo é resultado de pesquisa apoiada pelo CNPq, através de Edital Universal, processo 481611/2013-4. Também contou com apoio da Fundação de Amparo à Pesquisa do Estado de Alagoas (FAPEAL), através de edital PDPP, processo nº 60030 000686/2016. As contribuições de meus orientandos se fazem presentes nesse texto, muitas delas elaboradas nas reuniões semanais de discussão dos materiais. Sou grato a elas e eles pela experiência colaborativa. São eles: Andréa Laís Barros Santos e Beatriz Souza Vilela - Mestras em Sociologia, Ada Rízia, Alana Barros, Rangel Fidéles e Leonardo Prentse - graduandos em Ciências Sociais. Agradeço aos Juízes da Vara da Infância e Juventude, Fernando Tourinho e Ney Alcântara, pelas autorizações necessárias à condução desta pesquisa. Também agradeço aos diferentes superintendentes, educadores, assistentes sociais, psicólogas e, particularmente, aos monitores e jovens internos pela participação nos depoimentos e por tonar esta pesquisa possível.

* Fernando Rodrigues é professor do Instituto de Ciências Sociais e do Programa de Pós-Graduação em Sociologia da Universidade Federal de Alagoas (UFAL). Líder do GRUPPAES (Grupo de Pesquisa Periferias, Afetos e Economias das Simbolizações). E-mail: ferssa@gmail.com.
} 
Its focus is on the relationship between aspects of political power distribution - in police institutions and in the electoral system - and the reproduction of administrative instabilities in the social-educational system, which are reflected upon the standardization of disciplinary practices and ideals among instructors. Attention is directed to the recent increase of juvenile incarceration in Alagoas and the oscillation in the disciplinary management of this systems' units between a social educational perspective and a penitentiary approach.

\section{Keywords}

Agressiveness. Discipline. Juveline Detention Center.

\section{Introdução}

As direções dos impulsos de agressividade e de destruição manifestadas por um indivíduo são moldadas de maneira entrelaçada a todas as dimensões de sua vida afetiva. Elas são forjadas com outros e, sob esse condicionamento, forjam a personalidade de um indivíduo, com a qual age sobre si mesmo, e também opera consequências na vida dos outros (ELIAS, 1978; WINNICOTT, 2005). Os relatos de impulsos de brutalidade expressas por jovens encarcerados nas unidades de internação em Alagoas, onde faço observações e entrevistas, deu-me a oportunidade de problematizar a relação entre formas de agressividade e maneiras disciplinares praticadas em instituições de internação expressas nos vínculos entre jovens sob medida de internação e monitores de unidades.

Apesar do crescimento de pesquisas e publicações que tratam das dinâmicas disciplinares em sistemas penitenciários e socioeducativos no Brasil (DIAS et alli, 2013; SALLA, 2006; MISSE, 2007; MALLART, 2011; SANTOS e FREITAS, 1989; POTENGY, 2007; OLIC, 2009), ainda parece ser um desafio formular modelos que integrem as dinâmicas interacionais de agressão e cuidado entre populações encarceradas e agentes de estado e processos de transmissão intergeracionais de padrões de controle e autocontrole das emoções, especialmente aquelas que associamos a agressões e maus-tratos.

Os fenômenos de brutalidade que redundam, muitas vezes, no fim da vida de um indivíduo e das interações que o circundam são gestos humanos gerados sob atos e pressões advindas das relações entre indivíduos. A adequação de qualquer compreensão precisa levar em conta a concepção de que as agressividades de um indivíduo estão amarradas por gestos e 
símbolos a uma rede de pessoas (TILLY, 1969; ELIAS, 2002; MENNELL, 2007). Enxergar que as redes de pessoas que estruturam formas de cuidado e agressão de uma determinada situação pode ser compreendida por tendências processuais é um desafio que sofre fortes obstáculos. Alguns deles são as intensas polarizações sociais que facilmente fazem com que as tentativas de teorização tenham de assumir um comprometimento com posicionamentos político-sociais e assim com quadros bem definidos de certo e errado (SPIERENBURG, 1987, p. 439).

No estágio de desenvolvimento em que a sociedade brasileira se encontra, as guarnições policiais, as delegacias, o sistema judiciário e o "sistema de encarceramento" de adolescentes constituem algumas dessas dimensões da vida global que moldam as estruturas afetivas de jovens incriminados, moradores de bairros representados sob pesadas camadas simbólicas de rebaixamento de suas reputações. Também forjam os repertórios de expressões afetivas desses jovens os empreendimentos altamente criminalizados de entorpecentes e armas que proliferaram em periferias urbanas brasileiras na segunda metade do século XX. Tanto os atos de assassinatos, agressões físicas e torturas perpetrados por jovens contra adversários quanto as formas de repressão e controle de funcionários estatais, como juízes, policiais, agentes penitenciários e agentes socioeducativos sobre os jovens, tais como castigos físicos humilhantes, assassinatos sem legítima defesa, execuções sumárias ou outras formas de admoestações que reforçam fronteiras morais (MISSE, 2008) são expressões emocionais de indivíduos ligados por uma mesma configuração abrangente.

Os funcionários de unidades e jovens sob suas custódias formam uma rede de interdependências que fazem parte do processo, em curso, de estatização da sociedade brasileira e, em particular, da alagoana. Portanto, pode ser compreendida como uma dimensão estruturada da rede social da qual tanto os jovens quanto os funcionários fazem parte. Entender as maneiras como jovens e funcionários lidam com as pressões mútuas a que são submetidos por fazerem parte de um mecanismo de controle das liberdades em um sistema com função de punição e, normativamente, de estimular novos aprendizados pode ser útil para esclarecer as cadeias sociais de transmissão das agressividades em uma rede humana. As pressões advindas da restrição à liberdade mais ou menos padronizadas em práticas disciplinares não nos dizem apenas das afetividades de quem está preso e de quem realiza o controle. Diz-nos também de padrões sociais vinculados a pessoas que não estão diretamente ligadas ao "sistema", mas que pelos 
diferentes vínculos entre as pessoas deste e de fora dele podem nos trazer uma visão sobre as estruturas de poder e das emoções da sociedade mais abrangente. Especialmente, acerca de como seus membros lidam com o cuidado e com a punição daqueles que são vistos como uma ameaça. Afinal, há diferentes maneiras sociais de lidar com os medos que se afiguram aos nossos olhos. Uma das formas de lidar com a questão é investigar mais detidamente as figurações das ameaças e nossas ligações sociais com elas. Uma parte de como os brasileiros, e os alagoanos em particular, direcionam os seus medos sobre os grupos humanos párias estão condensados em unidades de internação.

Como ficará mais nítido a seguir, ao longo de mais de três décadas tem se retroalimentado um conjunto de tensões e ambivalências relacionadas às lutas por cargos estatais e à condução do sistema de internação alagoano, com implicações nas direções da padronização das práticas disciplinares dos monitores em relação aos jovens internos. Desde os anos 80, tem se reproduzido uma ambivalência de direções institucionais, estruturada por oscilações nos tipos de comando da superintendência socioeducativa, ora subordinada a concepções lúdico-educacionais ora sob condução militarpenitenciária. Tal oscilação reverberou na heterogeneidade das lógicas de recrutamento e de treinamento ao longo dessas últimas décadas, redundando na coexistência de monitores que reproduzem agonisticamente diferenças nos sensos de disciplina que poderíamos representar como uma convivência tensa entre dois habitus. De um lado, monitores que se reconhecem ou afirmam-se como educadores sociais, de outro, aqueles que se reconhecem ou se portam como um agente de segurança penitenciário.

Essa percepção se deu durante a pesquisa de campo. Desde 2012, frequento diferentes unidades de internação em Alagoas, nas quais pude fazer observações e entrevistar jovens internos e monitores. No interior das unidades não havia uma padronização da indumentária dos agentes de segurança. Tinham a liberdade para se vestirem de acordo com seus gostos, desde que estivessem de camisas e calças. Atualmente, os monitores trabalham uniformizados, mas do ponto de vista da identificação de diferenças de concepções e práticas disciplinares tal liberdade me permitiu observar uma regularidade. Alguns monitores utilizavam uniformes de segurança pretos semelhantes aos do batalhão de operações policiais, o BOPE da polícia militar de Alagoas, e outros vestiam roupas civis, geralmente calças, tênis, camisas polo e bonés. Ademais, ao longo das visitas, pude observar que entre os monitores uniformizados era comum maneiras 
mais formais e hierárquicas de se dirigir aos jovens, exigindo posição que demonstrasse respeito à autoridade, enquanto entre os que frequentemente vestiam trajes civis era mais comum observar um comportamento menos formal, expressando menor distância hierárquica entre o monitor e o jovem. Essa diferença de hexis corporal e de habitus disciplinar parece ganhar contornos mais nítidos ao mostrar um depoimento de um dos monitores entrevistados, indicando um senso prático de diferença que sentia como educador social em relação ao que considerava um agente penitenciário:

"Logo quando eu entrei no sistema nos foi dado umas camisas azuis que tinha atrás "agente de proteção", em outras tinha "educador social". Quando o sistema socioeducativo se juntou com o sistema penitenciário, aí os agentes tudo com a camisa SGAP, SGAP, GESP, quer dizer, os cara têm a ilusão com isso, que eu não tenho ilusão nenhuma. Mas tem gente que tem ilusão com isso. [...] Eu disse pra eles: “ó bicho, eu não consigo andar igual a você não". Os caras tudo com os aparato, camisa preta, calça rip-stop, coturno, não sei o quê, tal. Eu tenho uma botazinha, uma calça jeans e uma camisa. Aí os caras começaram a se sentir agente penitenciário porque unificou [os sistemas socioeducativos e penitenciário] Só que os agentes penitenciários cuidam de reeducandos, cumprindo penitência. Não é medida socioeducativa. É diferente. Os caras têm que separar isso. Nós somos agentes socioeducativos. E somos educadores sociais. Tem monitor que não deixa nem o cara ir na porta do alojamento conversar com o menor. Na verdade, o menor quer uma palavra". (Monitor "a" em depoimento ao pesquisador).

A percepção de diferença de perfis entre monitores que se consideram educadores sociais e aqueles que se reconhecem como agentes penitenciários serviu de porta de entrada para um conjunto de discussões a ser tratado neste artigo. Por que ao longo dos últimos 20 anos coexistiram entre os monitores diferentes sensos de seus papéis funcionais e das práticas disciplinares no gerenciamento dos jovens nas unidades? Quais as relações entre a configuração mais abrangente da sociedade alagoana que permitiu tal coexistência e as alterações nos padrões de agressividade de jovens internos, expressas em rebeliões, assassinatos de colegas de "celas", e outras formas de agressividade contra monitores? 


\section{A recente política de encarceramento de jovens em Alagoas: direções das agressividades enoveladas ao sistema socioeducativo}

Nos anos 2000, o aumento do encarceramento juvenil parece ter assumido especial relevância no estado de Alagoas, assim como em outros estados do Nordeste, indicando a expansão de uma lógica de atuação inédita de agentes estatais sobre a população, especialmente nos últimos 15 anos. Através de dados do governo federal, é plausível inferir tanto a maior atenção dada ao que tem sido percebido como um aumento de atividades criminalizadas, como o roubo e o tráfico de entorpecentes, quanto perceber mais enfaticamente um aumento do combate policial e judiciário a tais atividades praticadas por jovens residentes em zonas urbanas de baixa reputação social. É de se notar que, apesar de Alagoas não figurar entre os estados com maiores taxas de encarceramento de jovens - antes o contrário, figura entre os últimos - foi o estado em que ocorreu o maior aumento nessa taxa entre 2007 e 2012, variando 132\%, igualada apenas pelo estado do Espírito Santo, como se pode ver na tabela:

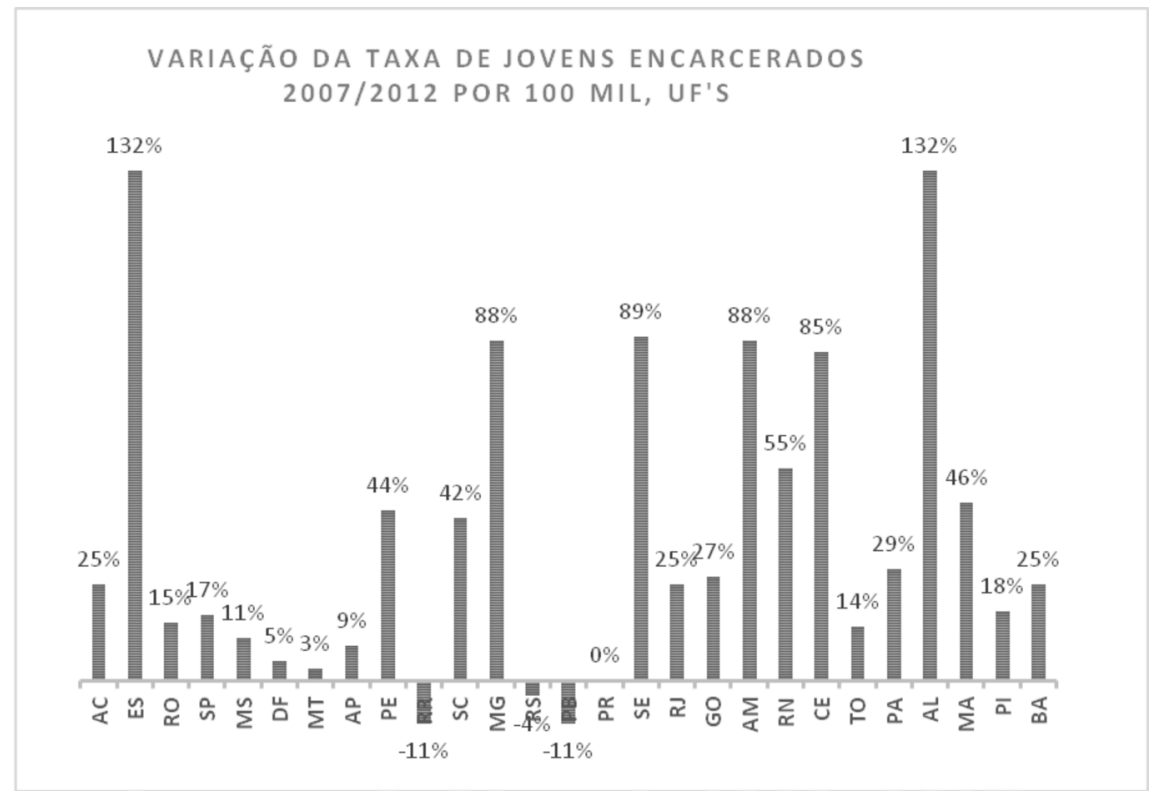

Fonte: Mapa do encarceramento: a juventude encarcerada, p.60 apud InfoPen e Waiselfiz. Elaboração do autor. 
Vale a pena notar que as variações dos estados do Espírito Santo e Alagoas destoam das de todos os outros estados do país, mesmo se considerarmos os aumentos expressivos nas taxas de encarceramento juvenil nos estados de Santa Catarina (42\%), Pernambuco (44\%), Maranhão (46\%), Rio Grande do Norte (55\%), Amazonas (88\%) e Minas Gerais (88\%). Esses dados, entretanto, dizem respeito aos jovens reclusos em penitenciárias, não sujeitos às obrigações legais de serem submetidos a ações de "ressocialização" inscritas no Estatuto da Criança e do Adolescente (ECA). Quando voltamo-nos para os dados sobre o encarceramento de adolescentes, por atos criminalizados de acordo com o ECA, os dados para o estado de Alagoas reforçam a ideia de que aumentou a percepção de crescimento da participação de adolescentes em mercados ilícitos, através de roubos e atividades associadas ao tráfico de entorpecentes, e, igualmente, do crescimento da atuação de vigilância e aprisionamento policial sobre essas atividades e esse público na última década.

Ao olharmos a variação da taxa de adolescentes em medidas socioeducativas de internação, observamos o crescimento de $16 \%$ no período 2011-2012, algo significativo, mas não acompanha de perto os estados com as maiores variações, Ceará e Paraíba, ambos com aumentos de 85\% (Anuário Brasileiro de Segurança Pública e Waiselfiz). Adicionalmente, o dado não mostra correspondência com a posição do Estado de Alagoas no encarceramento penitenciário de jovens.

Entretanto, quando observamos os dados sobre a variação na taxa de adolescentes que cumprem medida socioeducativa de internação provisória, as evidências de aumento da percepção da participação de adolescentes em mercados ilícitos e do crescimento da vigilância e punição da polícia e do judiciário sobre adolescentes moradores de periferias urbanas são nítidas. Destoa inteiramente de todos os estados da Federação. Vejamos a tabela: 


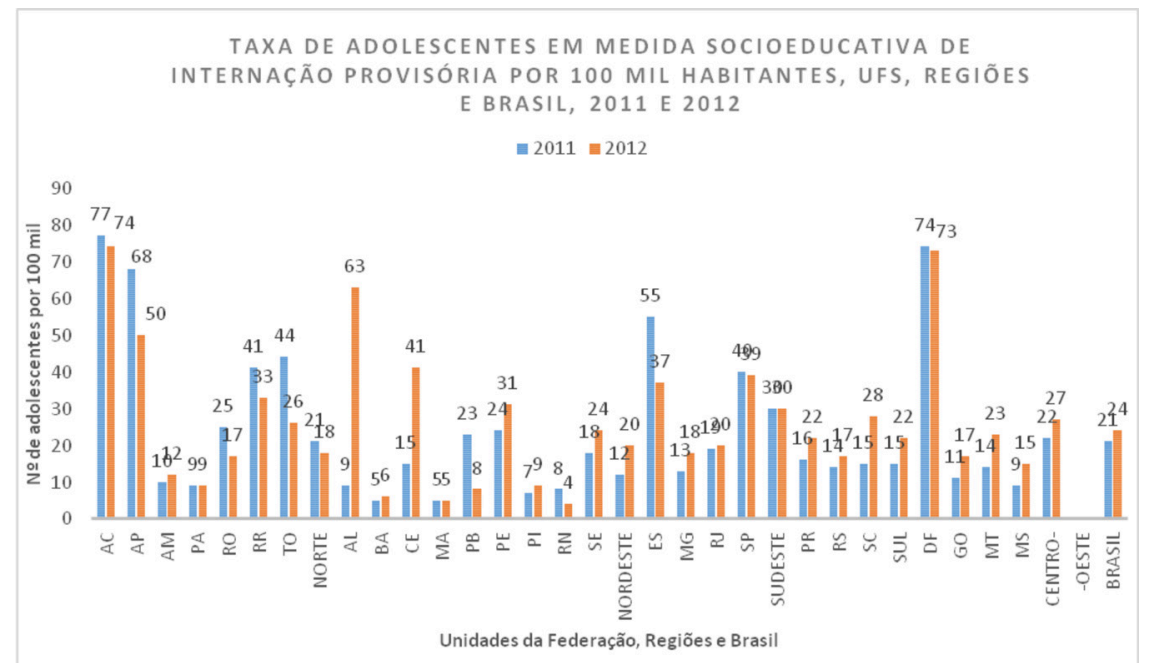

Fonte: Anuário Brasileiro de Segurança Pública e Waiselfiz. Elaboração do autor.

A variação da taxa de internos provisórios em Alagoas, no período 2011-2012, aponta crescimento de 601\%, saindo de 36 para 252 internações. Se relacionarmos esse dado com a variação de encarceramento juvenil penitenciário do Estado de Alagoas no período 2007-2012, de 135\%, ambas as maiores do país, temos elementos plausíveis para apontarmos uma alteração significativa e recente na vida de jovens alagoanos de "periferias" urbanas no que tange ao aumento de suas participações em lógicas específicas de mercados ilícitos (MISSE, 2011) e do aumento da vigilância e punição policial e judiciária nos espaços urbanos onde esses mercados ilícitos proliferam.

Um dos resultados não previstos da concorrência desses dois fenômenos foi o colapso das já precárias unidades de internação de jovens e adolescentes do Estado de Alagoas. Em 2013 e 2014, seguiram-se rebeliões, assassinatos de internos uns pelos outros (GAZETA DE ALAGOAS ORGANIZAÇÕES ARNON DE MELLO, 2013, 2014), tentativas de fuga e o escape de grandes grupos em curtos espaço de tempo (GAZETA DE ALAGOAS - ORGANIZAÇÕES ARNON DE MELLO, 2015), destruindo inteiramente algumas unidades. Ainda em setembro de 2013, a divulgação dos fatos chama a atenção do CNJ, que envia dois juízes para vistoriar o "Sistema", e afirmam constatar em seus relatórios um agravamento da situação em relação aos anos de 2011 e 2012 (G1 - GRUPO GLOBO, 2013). O Juiz da Vara da Infância e Juventude de Maceió, mediante pedidos da Defensoria Pública e do Ministério Público, decidiu pela intervenção nas 
unidades em diferentes momentos daquele ano, visando pressionar o poder executivo estadual a fazer algo (GAZETA DE ALAGOAS, 2014b). Aumentou-se a tensão entre a então denominada Secretaria da Promoção da Paz (SEPAZ) e a Vara da Infância e Juventude, culminando com a decisão desta última pelo fechamento da Unidade de Jovens e Adultos (18-21anos), em junho (GAZETA DE ALAGOAS, 2014a), e da Unidade de Internação Masculina (15-17) em dezembro, após uma fuga de grande quantidade de internos, proibindo, naquele momento, o encarceramento de novos jovens (GAZETA DE ALAGOAS - ORGANIZAÇÕES ARNON DE MELLO, 2014). As medidas foram tomadas sem uma solução alternativa em foco. Visavase forçar o poder executivo estadual a buscar alguma maneira de enfrentar o problema.

Acompanho esse curso de eventos desde 2012, quando iniciei a visitação a unidades de internação, observando algumas de suas dinâmicas e entrevistando funcionários e "socioeducandos". Ouvi relatos de depredações de "celas" lotadas, sucessivas tentativas de fuga, dificuldades de gerentes de unidades e fiscais conseguirem separar jovens que já tinham vínculos de rivalidades, por falta de espaço, vendo-se obrigados a improvisar novas "carceragens". Em alguns dias, algum monitor faltava, não informava ao fiscal que, por sua vez, não tinha como substituir a pessoa na equipe, diminuindo o contingente. Havia indícios de lutas internas ao sistema sobre a direção a ser tomada, com a intensificação de animosidades e desconfianças mútuas entre monitores, educadores sociais, equipe técnica, gerentes das unidades. Também éramos focos dessa desconfiança. Não foi possível entrar na unidade em diversas ocasiões, devido à tensão entre funcionários e internos. Sob essas condições, assim, reduziram-se as atividades socioeducativas devido à falta de lugares e condições adequadas quanto ao dever de evitar fugas e rebeliões, para que mais de uma turma de jovens pudesse participar de diferentes atividades simultaneamente. Ademais, em alguns períodos, ouvi relatos de comida de baixa qualidade, de redução do quadro de monitores, por diferentes motivos, abandono de emprego, demissões ${ }^{2}$, resultados de sindicâncias que constataram

\footnotetext{
${ }^{2}$ Diferentemente do sistema penitenciário de Alagoas, que aumentou significativamente seu contingente de funcionários através de concursos públicos nos últimos anos, o "sistema" de unidades de cumprimento de medidas "socioeducativas" é composto de funcionários com direitos trabalhistas restritos e precários. Monitores, fiscais, advogados, psicólogos e assistentes sociais são contratados como se fossem terceirizados. É importante ressaltar que Estados como o do Rio Grande Sul, nos anos 80, já realizavam concursos para o provimento de psicólogos sociais no seu sistema de unidades de internação. Ver (SANTOS; FREITAS, 1989).
} 
aplicações de punições ilícitas violentas. Entretanto, não houve reposição dos demitidos durante aquele período. Cresceu a tensão entre a Secretaria da Paz (SEPAZ), então responsável pelo Sistema de internação, e a Secretaria de Defesa Social, que passou a participar informalmente da administração, ainda em 2012. Houve a transferência de alguns agentes do sistema penitenciário para gerenciar unidades de internação, o que, como veremos a seguir, faz parte de um curso institucional que alimentou uma reiterada ambivalência entre direções da administração de jovens internos e dos seus regimes disciplinares. A preocupação principal, naquele momento, parecia ser, primordialmente, impedir as rebeliões e fugas. Ainda assim, tive oportunidades de iniciar a pesquisa, ter a colaboração da superintendência, gerentes, fiscais, monitores e funcionários da equipe técnica, dividindo seus espaços, muitas vezes precário, passando por diferentes alterações ao longo daquele ano, devido ao que seria o início de reformas prediais na unidade pela qual comecei as investigações [em 2012], até hoje [2015] não finalizadas.

À medida que ia conseguindo fazer entrevistas com os funcionários ${ }^{3}$ - alguns com 16, 17, 18 anos trabalhando em unidades de internação - e, alternadamente, com os jovens, foi-se abrindo uma dimensão do passado do sistema socioeducativo e do que, precariamente, poderia assinalar como expressão de tradições de administração e disciplinamento de jovens no sistema de internação alagoano. Cotejando esses depoimentos com as minhas observações, informações de arquivos e outras advindas de pesquisas do Serviço Social, chamou-me a atenção a luta entre diferentes grupos pela imposição de uma direção institucional para o sistema socioeducativo de internação desde os anos 80, quando podemos apontar a emergência da configuração atual das unidades com a criação do CRM (Centro de Recuperação de Menores), vinculado, à época, à Secretaria de Segurança Pública.

Entre as diferentes lutas, algumas envolvendo cargos, outras atreladas a possibilidades de poder político-partidário e de reforço de alianças pessoais, um conjunto desses embates poderia ser simplificado como uma disputa entre ideais de institucionalização de práticas de disciplina durante

\footnotetext{
${ }^{3}$ É sempre relevante assinalar que é uma dimensão aberta por pessoas ainda sujeitas às incertezas dos equilíbrios de poder no "sistema" de unidades e nas secretarias de estado às quais estão atualmente submetidos, com vínculos de emprego altamente precários. Apesar de muitos deles terem se disponibilizado a conceder entrevistas, essas incertezas estimulam um comportamento de elevado autocontrole na exposição de fatos da vida que o vinculam ao sistema.
} 
o internamento dos jovens. De um lado, segmentos defensores do que genericamente muitos denominavam educação social, e de outro, grupos que defendiam práticas disciplinares existentes no sistema penitenciário alagoano, o que, na prática, e um tanto silenciosamente, significava a extensão do regime disciplinar de presídios administrados historicamente por membros do exército brasileiro e da polícia militar estadual. A questão em relevo está relacionada à percepção de que, ao longo de quase 40 anos desde o início da "distensão" ditatorial e a "redemocratização" (ZALUAR, 2012), as práticas disciplinares nas unidades não parecem ter adquirido uma padronização sedimentada, seja em uma direção seja em outra, conhecendo sucessivos movimentos entre um polo e outro. Essa ambivalência de direções entre os polos "educação social" versus "disciplina penitenciária" pode servir para representar as práticas de monitores e do gerenciamento de seus trabalhos nas unidades de internação em Alagoas. Uma evidência da persistência dessa ambivalência sem que o processo assuma uma direção clara é um relato de um monitor que trabalha na unidade de internação há duas décadas:

Antigamente, assim, a gente vinha trabalhar era com um pensamento. Hoje o cara vem trabalhar diz assim: "Tem carteira? Pode usar carteira? Pode usar arma?". Hoje...

$[\ldots]$

Cê vê... [apontando para um colega vestindo um uniforme preto, à semelhança de um policial do BOPE.] É pintado de preto.

Eu num trabalho desse jeito, num gosto.

Entendeu? Trabalho aqui: "Vamo pra horta!", antigamente a gente acordava seis e meia da manhã. $\mathrm{O}$ adolescente, arrumava o alojamento, forrava, saía, tomava o café e ia pá atividade. Na época aqui a gente num tinha uma escola, tinha, era um refeitório. Uma professora dava aula, só, num precisava de muito. [...] E era quarenta adolescente. Já trabalhei cum cento e cinco adolescente, cum oito monitores. Na cidade hoje tem sessenta e pouco, tem doze monitores e ainda é pouco.

[...]

F- O que que mudou do jovem?...

- [...] Do jovem, assim, hoje tá mais ou menos assim: o adolescente tá mais organizado hoje, hoje é mais tráfico. Antes era mais o quê? Era homicídio, era o furto, era o roubo... Hoje não, PI: além de ser tráfico, ele comanda.

$[\ldots]$

- Além de ser traficante, comanda. Do comando.

(Monitor " $b$ " em depoimento ao pesquisador - Grifos meus). 
Do relato, destaco dois fenômenos entrelaçados ao desenvolvimento do sistema de unidades de internação de Alagoas desde fins dos anos 90. De um lado, o fato de que o perfil de quem vem trabalhar nas unidades mudou, ressaltando a primazia atual de candidatos e indicados na busca por prestígio e insígnias profissionais aproximadas das de um agente penitenciário ou policial militar: a carteira, a arma e um uniforme de segurança parecido com os usados por policiais do Batalhão de Operações Especiais, o BOPE de Alagoas. O posicionamento do monitor expressa a distância social que mantém da concepção de outros monitores empregados no sistema, associados a uma concepção de disciplina penitenciária e policial, reconhecendo-se como um agente que expressa uma afinidade com ideais de um educador social. Um dos aspectos principais desse conjunto de ideais é a busca por reduzir índices de distância social e hierarquização entre monitores e jovens, expressa nas roupas e nas possibilidades de conversa e aconselhamentos entre monitores e jovens dentro das unidades, enfatizando a exigência de disciplina pelo que denomina "mútuo tratamento de respeito".

De outro, destaco em sua fala a mudança no perfil dos jovens que, segundo seu relato, estariam mais organizados, mais ligados ao tráfico de entorpecentes e mais dispostos a se orientarem por padrões de organização e de liderança mais coletivas e menos instáveis. Dessa menção, inferi que se referia a uma acentuação da associação entre senso de pertencimento grupal e padrões de agressividade armada ligados a sociabilidades de jovens que gravitam em torno de bocas de fumo e residências de aluguel em "periferias", como pude observar em entrevistas com internos, onde se concentram homens jovens traficantes que, de algum modo, rompem seus relacionamentos doméstico-familiares e passam a expressar sensos de pertencimento à "facções". O tipo de afirmação anteriormente citado não foi isolado. Encontrei-o em diferentes falas de interlocutores que trabalhavam nas unidades, o que me alertou para uma diferença geracional entre funcionários do sistema de internação que poderia condensar uma diferença entre configurações das instituições estatais de Alagoas no tempo.

Em foco, está a percepção de monitores mais antigos de que, aproximadamente no início dos anos 2000, as unidades eram mais orientadas por monitores com um ethos de "educador social" e que, na segunda metade dos anos 2000, a tendência foi o recrutamento de pessoas com uma predisposição a um ethos de monitoramento nas unidades com afinidade com o de um agente penitenciário, com uma visão de mundo 
próxima ao estilo de postura, indumentária e hexis corporal de um policial militar, ainda que sem passagem por centros de treinamento diferenciados, como as academias de polícia, ou seja, com ainda mais baixa formalização de seu aprendizado profissional. Nos depoimentos entre os mais velhos, também encontrei a percepção de mudança da atitude do jovem no espaço das unidades. Antes, haveria mais convivência e espaços de conversas entre monitores e jovens. Aconselhamentos, confidências, participação em jogos de futebol ou relações de mestre-artesão. Alguns deles indicaram também uma mudança no tipo de comportamento pelo qual os jovens passaram a ser incriminados, destacando-se o vertiginoso crescimento de jovens encarcerados por comportamentos tipificados como tráfico, que, para as periferias urbanas de cidades nordestinas, particularmente de Alagoas, é um fenômeno específico dos anos 2010.

Como clara evidência da mudança nas potenciais ligações das vidas de jovens das "periferias" maceioenses "recrutados" pelo sistema judiciário e socioeducativo nos anos 2000, temos, por contraste, uma pesquisa realizada pelo Núcleo Temático da Criança e do Adolescente da UFAL, no ano de 1994, na Delegacia da Criança e do Adolescente. O tráfico de drogas sequer aparece como uma categoria autônoma de classificação das apreensões que, entre janeiro e junho daquele ano, produziram 1183 ocorrências assim sistematizadas:

Motivos das apreensões

\begin{tabular}{|l|c|c|}
\hline \multicolumn{1}{|c|}{ APREENSÕES } & Abs & $\%$ \\
\hline $\begin{array}{l}\text { Atentado ao patrimônio (Furto arrombamento, depredação, } \\
\text { receptação de furto e pichação de muro }\end{array}$ & 675 & 57 \\
\hline $\begin{array}{l}\text { Atentado aos costumes (desordem, drogas, sedução, } \\
\text { difamação, porte de arma e identidade falsa) }\end{array}$ & 367 & 31 \\
\hline $\begin{array}{l}\text { Motivos triviais (desocupado, fugitivo, perdido, achar } \\
\text { documento, namorando, viajando pra casa, entre outros) }\end{array}$ & 77 & 6,5 \\
\hline $\begin{array}{l}\text { Atentado à pessoa humana (lesão corporal, homicídio, } \\
\text { acidente de trânsito) }\end{array}$ & 29 & 2,5 \\
\hline Outros & 15 & 1,3 \\
\hline S/inform. & 20 & 1,7 \\
\hline TOTAL & 1183 & 100 \\
\hline
\end{tabular}

Fonte: Malta e Veras (1998, p. 49) - Pesquisa documental NTCA/UFAL-Janeiro/ Junho/1994. Delegacia da Criança e do Adolescente. 
Essa tabela nos dá uma visão do repertório normativo das concepções policiais da sociedade maceioense dos anos 90 e também do tipo de preocupação de pesquisadores do Serviço Social sobre "jovens infratores" do período. Adicionalmente, nos dá uma dimensão sobre o baixo percentual de ocorrências policiais associadas à apreensão de jovens capturados por atos de agressividade letal. O tráfico de entorpecentes e o homicídio estão entre as tipificações policiais de comportamento de jovens com menor ocorrência no período, o que nos permite inferir que não era algo que tomava a atenção prioritária dos policiais e pesquisadores. Naquele contexto, estavam prioritariamente orientados para as formas de repressão do estado e a situação de vulnerabilidade social de crianças e adolescentes que moravam nas ruas de Maceió.

Para entendermos a configuração que gesta o aumento intenso do encarceramento juvenil nos anos 2000 em Alagoas, em parte associado ao aumento do tráfico e da criminalização do tráfico de entorpecentes, é importante lançarmos um olhar sobre a feição do estágio de desenvolvimento do estado em Alagoas nos anos 90. Assim, podemos posicionar o problema das direções ambivalentes das práticas disciplinares do sistema socioeducativo, associando-o à intensificação da informalidade urbana, ao tipo de centrifugação do uso da força armada em curso naquele momento e ao curso subsequente do colapso fiscal e administrativo do estado alagoano conhecido no governo Suruagy, em 1997, após adoções sucessivas de diretrizes neoliberais para o já enfraquecido estado alagoano.

\section{0 colapso fiscal do estado de Alagoas, informalização da economia urbana e forças centrífugas de violência: as mudanças no sistema de internação alagoano no final dos anos 90 e início dos anos 2000}

A oposição que encontrei entre monitores que se identificavam com um ethos de educador social e monitores que se identificavam com um ethos de agente penitenciário e policial, convivendo e desempenhando funções de vigilância nas unidades de internação, levou-me à busca por compreender a existência de tal configuração. Detectei que os mais velhos, entre os quais encontrei mais frequentemente a avaliação de que "antes" - no início dos anos 2000 - "tinha uma maneira melhor de se trabalhar", haviam majoritariamente ingressado no "sistema" durante o primeiro governo Ronaldo Lessa (1998-2001) e no primeiro governo Theotônio Vilela Filho 
(2006-2009). Ronaldo Lessa havia alcançado a liderança do estado com o apoio de uma coligação de partidos reconhecidos como de esquerda e que, durante o mandato, conheceu uma desagregação de sua base parlamentar, reconfigurando o arco de alianças político-partidárias, com reverberações na execução de políticas nas secretarias de estado (VASCONCELOS, 2003; CARVALHO, 2015).

As condições de recrutamento dos monitores, entretanto, seriam muito deficientemente representadas se buscássemos razões unilaterais associadas a bandeiras partidárias, sem que tornemos evidentes as dinâmicas práticas que vinculavam as associações de poder político partidário para assegurar "governabilidade" e as direções concretas de execução de políticas nas secretarias de estado.

Uma associação de fatores para o recrutamento de monitores no período que antecede o governo Lessa está relacionada com o colapso da estrutura burocrática do Estado de Alagoas que culminou, em 1997, com um tiroteio entre forças policiais e do exército e a queda do governador Divaldo Suruagy. Entremeado a esse curso de eventos, se desconstruíram diferentes órgãos estatais. O estado e sua burocracia conheceram uma bancarrota expressa em atrasos salariais de mais de seis meses, o aumento significativo de suicídios e o aumento de prestação de serviços ilegais por agentes do estado, buscando fontes alternativas de dinheiro. O principal braço do funcionalismo que liderou o levante contra o governo foi a polícia militar, que também conhecia os efeitos da desorganização e da falência das finanças do estado (ALVES, 1998) ${ }^{4}$. Ademais, foi também no seio da polícia militar que surgiu e proliferou durante os anos 80 e 90 um grupo paramilitar conhecido nacionalmente como a "gangue fardada", especializada em prestação de serviços ilegais, incluindo assassinatos mediante pagamento, para lideranças econômicas e políticas estaduais. Esses grupos expressavam o elevado gradiente de centrifugação das forças armadas na resolução dos conflitos e das ameaças sociais entre diferentes setores da sociedade alagoana.

\footnotetext{
${ }^{4}$ Em 1997, antes de se afastar do governo do estado, Divaldo Suruagy sofreu diversas pressões da alta cúpula federal do governo Fernando Henrique Cardozo para que rompesse o acordo de renúncia fiscal com os usineiros, condicionando uma ajuda financeira federal a uma intervenção informal em seu governo, através da escolha do Presidente da República de nomes para a administração das secretarias da Fazenda, Planejamento, Segurança Pública e Administração.
} 
Uma parte da vida dos jovens que vivia nas ruas, reconhecidos por concepções não coincidentes entre si, como "menores carentes", "menores abandonados" ou "menores infratores", estava nas mãos de grupos policiais que prestavam serviços ilegais de assassinatos. A descentralização do uso da força contra jovens era tão elevada que podia ser vista na atuação de grupos paramilitares, ligados a membros da polícia, organizados como batalhões de guardas-mirins. Havia uma exploração econômica dessas crianças e adolescentes por indivíduos da corporação. Um relato de Malta em 1990 é bastante elucidativo:

“A novidade era então, a ação repressiva dos policiais-mirins. Eram meninos, moradores da periferia, recrutados e treinados na função de guardas-mirins em uma entidade não-governamental dirigida por um policial, recebendo fardamento e posterior contratação pelos comerciantes de lojas do comércio e do mercado municipal para manterem a ordem, evitarem pequenos furtos e prestarem apoio na repressão aos meninos de rua [...] Até finais de 93 já se constituíam cinco batalhões mirins e juvenis com idades de 12 a 17 anos, desenvolvendo atividades de vigilância patrimonial e policiamento para dar segurança aos comerciantes, adotando inclusive regras hierárquicas rígidas e uniformes. Prestavam serviços específicos do poder público, como o de prender, reprimir e ainda espancavam e perseguiam meninos em situação ode rua. Estavam sujeitos à mesma disciplina dos quartéis. Patrulhavam as ruas de segunda a sexta-feira, durante todo o horário comercial ou ficavam parados nas portas das lojas como "sentinelas". Após uma série de denúncias envolvendo esses "soldados-mirins" em vários conflitos, a ponto de um juiz estadual proibir que usassem cassetetes ou qualquer tipo de arma, o presidente do Conselho Municipal dos Direitos da Criança denunciou essa situação à $\mathrm{OAB}$ e pediu à Procuradoria da República a extinção dos cinco batalhões, convencido de que por trás dos meninos estavam adultos oportunistas, que usavam o clima de insegurança como meio de ganhar a vida. Denunciou também, o presidente do Conselho, que os "soldados dos batalhões" da polícia-mirim faziam prisões arbitrárias e não podiam ser responsabilizados porque eram menores e, por outro lado, não dispunham de garantias trabalhistas, o que infringia o Estatuto da Criança e do Adolescente".

(MALTA, 2009, p. 48).

O trecho é uma evidência de como o uso da força se subordinava a uma configuração com elevados gradientes de descentralização, ainda que, 
de um ponto de vista de maior duração, marcados por um processo de aumento da gravitação das oportunidades de poder militar em torno da polícia estadual, se comparado a décadas anteriores. O padrão de dispersão tinha um limite, que era a capacidade de membros da corporação militar arregimentar fidelidades em nome de negócios em nome próprio mas que, em última instância, se lastreava na possibilidade de intimidação ligada ao temor da mobilização de membros da corporação para a proteção de tais negócios ilegais. A questão fiscal é um dos fatores para se compreender o tipo de distribuição do uso da força e desse tipo de economia emocional agressiva associada a membros das polícias militares.

Apesar de boa parte de analistas da imprensa e das universidades responsabilizarem a falta de capacidade do governo Suruagy, que já havia governado o estado outras duas vezes, além do mandato em que foi deposto, a crise institucional mostra-se incompreensível sem uma avaliação da falência fiscal do estado. Em grande parte, foi decorrência da aliança entre diferentes segmentos das elites econômicas alagoanas em torno da renúncia tributária sobre os principais produtos e serviços de Alagoas. O setor sucroalcooleiro perdeu a proteção do governo federal angariada durante os governos militares, através de programas como o Proálcool e as facilidades de crédito rural por meio do Banco do Brasil, muitas dívidas desses empréstimos tendo sido anistiadas (SANTOS, 1999, pp. 52-55). Esse movimento se deu em meio ao complexo e intricado processo de redemocratização (ZALUAR, 2012) e, muito menos falado, de reformulação do equilíbrio entre as unidades federativas, entre os anos 80 e 90, fazendo com que os grupos usineiros perdessem espaço para as usinas paulistas. Aqueles buscaram amenizar as perdas através de pressões para que o Estado de Alagoas reduzisse a pressão do fisco sobre suas atividades, ainda no início dos anos 80, tendo esse acordo sido fortalecido no governo estadual de Collor de Mello, que agravou a situação fiscal aplicando medidas orientadas por um horizonte de ideais econômicos "neoliberais" combinadas com tradições de recrutamento de funcionários públicos estáveis por indicações pessoais que perdurariam até o governo Geraldo Bulhões. Concretamente, tais movimentos redundaram na combinação entre redução fiscal, aumento do funcionalismo público sob o regime jurídico único, e o incremento de novas formas de endividamento público, criadas pelos governos militares, que repercutiram em um enfraquecimento dos estados diante da União (ALVES, 1998; LOPREATO, 2002). O rumo dos eventos fez convergir o declínio da economia sucroalcooleira e o da arrecadação sobre o setor, corroendo o 
tecido social vinculado à burocracia do estado de Alagoas. Isto ajudou a intensificar a polarização entre setores sociais que culminou com o colapso de inúmeras autarquias, dentre elas, o órgão responsável pela assistência social e pela internação de crianças e adolescentes: a FUNDAC. O processo de estatização da vida de jovens familiarmente vulneráveis em uma direção psicológico-educacional encontrou um revés. Tal destruição institucional se entrelaçou ao fortalecimento relativo de um sistema prisional em expansão, fazendo com que o equilíbrio de poder entre funcionários estatais pendesse para os agentes penitenciários. Estes estavam se organizando como classe de funcionários estatais a partir do primeiro concurso público nos anos 2000. Os funcionários do sistema socioeducativo, diferentemente, passaram a ser regularmente contratados sob regimes jurídicos "precários". Assim, as "crises" enfrentadas pelo sistema socioeducativo a partir dos anos 2000 frequentemente foram "tratados" com a eventual intervenção de funcionários do sistema prisional, gerenciando unidades ou até mesmo a superintendência.

Como destaca Malta (2009), a FUNDAC, criada em 1992, era uma continuação da mesma estrutura existente na antiga FEBEM-AL, órgão estadual que, legalmente, deveria seguir as diretrizes e princípios fornecidos pela FUNABEM, entidade federal. Efetivamente, entretanto, os recursos se concentravam na organização da FEBEM do antigo Distrito Federal, no Rio de Janeiro, e as fundações estaduais se desenvolviam sob uma configuração altamente descentralizada e sem integração nacional, não havendo quaisquer formas de controle das atividades segundo os termos federais inscritos na lei ${ }^{5}$. Dessa forma, a organização da FEBEMAL, que já existia em 1976, como consta no documento da CPI do menor realizada naquele ano, estava inteiramente subordinada à configuração política e administrativa estadual. Isso significa dizer que, efetivamente, estava submetida às pressões emocionais moldadas prioritariamente por uma estrutura de divisão de poder altamente centrífuga e bastante instável. As principais forças de constrangimento e de autoconstrangimento estavam vinculadas às alianças entre os grupos que ocupavam a assembleia estadual e negociavam as posições em secretarias, com lideranças do executivo, visando a oportunidades políticas, econômicas e de prestígio. O horizonte

\footnotetext{
${ }^{5}$ Ver CPI do Menor (1976).
} 
de avaliação dessas oportunidades e as tradições de negociação e resolução dos conflitos por poder eram moldadas por redes de compromissos familiares e clientelistas que interligavam pessoas de diversas cidades do interior e de Maceió, uma capital muito pressionada pelas forças centrífugas expressas em redes de fidelidades de parentesco e patronagem formadas em municípios do interior do estado, geralmente subordinados às conexões afetivas que gravitavam em torno de plantações de cana e de usinas na zona rural. A ocupação de cargos do funcionalismo estadual estava subordinada a essa estrutura. As alterações na distribuição de poder significavam mudanças nas hierarquias no interior das secretarias, e as oscilações nas redes de alianças estaduais reverberavam no interior das autarquias. Por divergências entre grupos, um funcionário podia continuar recebendo, mas afastado de qualquer atividade estatal, evitando que tivesse interferência em um governo sob liderança de algum adversário. Projetos iniciados eram finalizados subitamente, novos projetos eram elaborados, ou simplesmente reproduziam o hábito burocrático, criando um efeito de trava institucional. Os conflitos entre grupos de funcionários, homólogos às redes clientelistas que haviam tornado possível seus recrutamentos, reproduziam-se constituindo diferentes forças centrífugas em relação às tentativas de padronização e autonomização de ideais e práticas autárquicas. As fidelidades políticas, emergidas das do clientelismo e do parentesco, mantinham as tensões entre grupos de funcionários em níveis elevados, muitas vezes, impedindo a institucionalização de práticas e de diretrizes de funcionamento das autarquias.

É plausível pensar que a centrifugação relativa do controle do uso da força no estabelecimento de punições, como os observados em corpos paramilitares de vigilância e punição em bairros "periféricos" controlados por membros da polícia, também estivesse presente nas delegacias da criança e do adolescente e unidades de internação da FEBEM no final dos anos 80. Em um relatório de pesquisa com crianças e adolescentes de rua, elaborado em 1989 pelo mesmo NTCA-UFAL, são apontados os tipos de abordagem policial indicados pelos entrevistados: "maus-tratos, espancamentos, bolos, choque e pau-de-arara e péssimas condições de alimentação, de higiene ('com mijos de rato, baratas e cheiro de urina') e de alojamento, já que dormiam no chão" (MALTA, 2009, p. 39).

Qual é a origem, então, da lembrança de alguns monitores de que no final dos anos 90 e início dos anos 2000 a concepção de trabalho era "melhor", no sentido de que seguia princípios de educação social e não de 
práticas penitenciárias, tais como habituamos a associar práticas de tortura e castigos punitivos?

Ela está relacionada com o desmantelamento da FUNDAC e de outras autarquias do estado de Alagoas, e à transformação nas redes de alianças políticas propiciadas pelo colapso fiscal do Estado de Alagoas entre o final dos anos 90 e o início dos anos 2000. Ademais, tais lembranças foram formadas após o declínio vertiginoso da configuração de elites locais e regionais propiciadas pela perda relativa de importância das economias da cana e do fumo na formação das estruturas das emoções e das formas de agressividades. Alguns dos padrões de controle e o autocontrole dependentes da vigilância exercida sob um "regime de segurança" dominado quase que diretamente pelos usineiros, de feição miliciana, passará a ser exercido mais pronunciadamente por guarnições e batalhões de polícia, que gradativamente deixam de ser fornecedores de indivíduos para milícias de grupos políticos e econômicos, e se torna um polo gravitacional de organização de empreendimentos privados e "centros centrífugos" da implementação de "justiça" em bairros de periferia. Em outros termos, a memória de alguns monitores diz respeito a um conjunto de episódios recentes que, quando posicionados numa perspectiva de maior duração, expressam pressões de mudança de direção nas estruturas de repressão do estado de Alagoas sobre práticas ilícitas de jovens em uma cadeia de pressões mais sedimentadas de uso não regulamentado da força nas dinâmicas de punição e disciplinamento de jovens sob custódia do estado de Alagoas.

\section{As oscilações na administração do sistema de internação e as direções ambivalentes de agressividade e de cuidado entre funcionários do estado sobre os jovens encarcerados}

As eleições de 1999 expressaram com nitidez as alterações profundas de desconstituição da rede de alianças políticas e econômicas do estado vigentes desde o início da ditadura militar (CARVALHO, 2015). A corporação policial não estava tão próxima dos grupos políticos que controlavam o poder estatal como antes, como expressa a desintegração da gangue fardada nos anos 90 . Os grupos da elite política haviam perdido uma boa parte de seu prestígio com a bancarrota estatal conhecida sob seu poder. Aumentou-se a importância cultural e política de diferentes 
grupos de classes médias citadinas de Maceió, ligados às igrejas católicas e protestantes, à universidade e a agentes emergentes do judiciário, como promotores e advogados, que também mantinham muitas diferenças e conflitos entre si (VASCONCELOS, 2003). A ascensão de Ronaldo Lessa, o único prefeito eleito de Maceió que se tornou governador de Alagoas, expressava o crescimento do poder político de grupos citadinos não detentores de poder militar. Durante um período de seu governo, a administração das unidades de internação deixou de estar nas mãos de grupos do sistema policial-penitenciário, ficando alocada na recém-criada Secretaria de Justiça e Cidadania (Sejuc), especialmente a partir de 2001, sob a condução do secretário Tutmés Airan. A FUNDAC não mais existia, tendo muitos de seus funcionários solicitado transferência para outras autarquias ou aderido ao Plano de Demissão Voluntária. Assim, abriu-se espaço para que indivíduos formados sob ideais jurídicos e educacionais "dos direitos humanos" assumissem a superintendência de medidas socioeducativas, conduzindo também um novo ciclo de contratações de monitores. Como efeito das políticas de reforma do estado, os funcionários contratados não tinham mais estabilidade. Seus contratos eram a título precário, sem direitos previdenciários ou seguros sociais.

Oriundos de diversas redes de contatos pessoais, através das quais as vagas na secretaria eram divulgadas, os contratados passaram por um conjunto de treinamentos, incluindo a formação em direitos humanos e a transmissão de um conjunto de princípios de que a monitoria estava associada a atividades de "educação social". O depoimento de dois monitores é expressivo sobre algumas das atividades desenvolvidas por eles, nesse período:

Eu já levei menino pra praia, pro circo...

Isso foi em 2005, 2004. Marco Frota, quando veio aqui, levei pro circo...

[...]

Pá praia, Praia do Saco...

[...]

Pro cinema...

[...]

Porque assim? as pessoas que assumia era, tinha, acho que você conhece a Maria da Graça.......] Ela era, assim, a pessoa que tinha o pensamento diferenciado aqui. Olha c'os outros olhos. E o tratamento também, entendeu? com adolescente. Mesmo que eles são infrator, mas se você dá respeito... 
[...] E olhe, quando chega adolescente meu aqui no meu plantão, eu sempre pergunto: "Qual o seu direito? Cê sabe seu direito?", "Não...", "Ser respeitado.", ele olha assim pra mim: "É um direito seu: ser respeitado.". Começo a conversar sobre deveres, se você dá respeito, você recebe respeito. [...]

Hoje, se você conversar com o adolescente, [algum colega] vai dizer: “Oxe, qué isso? tá conversando com vagabundo?!”, [olha o] pensamento, a mente...

(Depoimento do monitor " $\mathrm{b}$ " ao pesquisador)

Outro monitor relatou:

“A gente fazia muito curso na época do Tutmés Airan, com psicólogo, com assistente social, com oficiais da PM, com secretário. [...] Aí sempre o psicólogo falava pra mim que a arma mais necessitada para um homem, para ele próprio, era a língua. Saber convencer uma pessoa de que ela estava errada. [...] A arma, de cintura, de fogo, ou bastão, pra se defender, como defesa pessoal, isso só em último caso. Só se a gente fosse agredido, mas primeiro era a conversa. Isso foi mais ou menos em 2000, 2001. [Tutmés Airan assume a secretaria em 2001] tinha curso de seis em seis meses. Demorava uma temporada, e vinha outra etapa. Defesa pessoal, primeiros socorros, tinha tudo isso naquela época, hoje não tem mais. [...] Trabalhar com adolescente menor infrator é um trabalho diferente do pessoal do presídio".

(Depoimento do monitor " $\mathrm{d}$ " ao pesquisador)

Ocurso de padronização deumethos deeducador social entre os monitores que administravam a vida de jovens sentenciados por atos ilícitos conheceu diferentes reveses. O principal deles está relacionado com o funcionamento temporário das unidades de internação de menores conjuntamente com o sistema penitenciário em 2005, após a saída de Tutmés Airan da Secretaria de Justiça e Cidadania. O sistema socioeducativo passou a funcionar sob os mesmos padrões do sistema penitenciário, subordinado à Secretaria de Ressocialização, aumentando os espaços de comunicação entre presidiários e adolescentes "internos", incluindo a participação em mercados ilícitos de drogas e sexo no interior das penitenciárias, dependente de funcionários. Nesse sentido, o sistema de internação voltava a alinhar-se com o curso de desenvolvimento do sistema policial e penitenciário estadual. Essa aproximação entre sistemas durou algo em torno de 2 anos. O recrutamento de funcionários das unidades de internação sofreu alteração. A rede de 
educadores que exercia poderes de contratação cedeu lugar a grupos vinculados ao sistema penitenciário, com ligações indiretas com setores da polícia militar. O próprio sistema penitenciário passava por intensas transformações, com setores que lutavam entre si, um pela manutenção do recrutamento associado às indicações políticas, outro reivindicando o recrutamento por concurso público. Um dos monitores entrevistados relata:

Monitor - Desde quando era... Quer dizer, desde que... Não... De Fundac. É, desde Ronaldo Lessa. Desde Ronaldo Lessa, quando passou Fundac. Porque antes era Sejuc, depois era Fundac. A Fundac foi extinta. Passou pra Sejuc. Aí, quem tomou conta da Sejuc era a administração do Sistema Penitenciário. Aí, mudou o perfil do monitor. Houve a migração dos agentes pra cá, aí, já chegou o diretor pra mim e disse: "Num quero não monitor conversando com adolescente", aí, disse: "Você vai ficar medindo força, é?".

F- Entendi. Mas qual era o perfil do pessoal que chegou depois?

Monitor - Rapaz, o critério era de segundo grau, formação. Tem de todo jeito...

F- Mas eu falo assim: os padrinhos, eles tavam ligados à polícia, ao sistema penitenciário?

Monitor - Não, antes era mais setor civil, assim, no meu caso, quem m'indicou foi um professor de capoeira [...] Hoje, a gente passou um tempo pra cá, quem assumiu foi coronel.

Com orecrutamento denovos monitores avaliados por superintendências vinculadas ao ponto de vista da tradição penitenciária brasileira, misturouse dentro das unidades funcionários com pontos de vista de educadores sociais e de agentes penitenciários. Essa aproximação deu-se em uma configuração na qual novos agentes jurídicos angariaram mais poder para pressionar os poderes públicos para reduzir práticas brutais de uso da força física, especialmente promotores e juízes da infância e juventude, após a nova constituição de 1988. Ambos os tipos de agentes da justiça aumentaram as suas participações na vigilância do sistema de internação decorrente do aumento das forças de integração nacional em torno da padronização de ideais e práticas que reprimissem e contivessem a brutalidade física de agentes estatais como maneira de punição e exercício da disciplina, expressa pela aprovação do Estatuto da Criança e do Adolescente. Essas pressões também repercutiram no perfil de secretários responsáveis pelo sistema de internação. Entretanto, uma parte importante da administração do sistema socioeducativo ainda estava nas mãos de agentes do sistema 
penitenciário. Formava-se, assim, uma estrutura de interdependências pessoais e institucionais altamente instável no interior do sistema de internação que tendeu a reproduzir a ambivalência do direcionamento das práticas disciplinares entre as equipes de monitores que se sucederam nos governos seguintes.

Fora das unidades, aumentava-se a pressão de diferentes setores de sociedade alagoana para lidar com o crescimento de eventos brutais perpetrados por jovens em bairros periféricos e, concomitantemente, sobre os agentes do sistema. Eles que recebiam o aumento intenso das pressões por encarceramento da polícia e do judiciário e igualmente representadas sob pesadas camadas de rebaixamento de seus valores humanos. Setores da sociedade alagoana exigiam reformas no sistema de internação, outros setores exigiam redução da maioridade penal, e assim, mais prisões de jovens. Assim, a consequência foi o aumento do encarceramento juvenil em um contexto de aumento da instabilidade entre funcionários do sistema, em instalações precárias e submetidos às pressões e padrões do sistema penitenciário de então.

Não parece ter sido um episódio isolado e sem conexões prévias a rebelião de 2005 no sistema de internação, no antigo presídio de São Leonardo, hoje fechado e transformado em uma colônia industrial, que, a partir das lembranças de monitores mais antigos, foi a mim relatado como a primeira grande rebelião organizada dentro da unidade de internação. A peculiaridade dessa rebelião estaria na direção da agressividade dos jovens encarcerados, que miravam os funcionários, mostrando algum nível de organização entre os internos. Nos relatos desses monitores, as confusões e brigas nas unidades nos anos 90 estavam circunscritas a rivalidades entre os jovens, ou tentativas isoladas de fuga, que redundavam em eventos brutais, como a morte de adolescentes (DRYBREAD, 2014). De seus pontos de vista, as rebeliões de unidades inteiras, eventos vistos nas FEBEMs de São Paulo nos anos 80 e 90, transmitidas por televisões nacionais, que reivindicavam direitos em uma linguagem jurídica, visando a melhorias nas condições de encarceramento, de tratamento por funcionários das unidades (FELTRAN, 2010; OLIC, 2009), foi algo conhecido por eles apenas após 2005, quando a unidade de internação passou a funcionar conjuntamente com o sistema penitenciário.

Apesar da aproximação durante dois anos, não ficou sedimentado entre as lideranças do executivo estatal que o sistema de internação ficaria sob responsabilidade de funcionários amadurecidos nas tradições de vigilância 
e disciplina penitenciária. Desde 2005, o sistema mudou de secretaria diferentes vezes e, associado a essas mudanças, os sistemas de recrutamento e as direções de padronização do trabalho de equipes técnicas e monitores dentro das unidades.

A aproximação de funcionários com tradições de pensamento e práticas diferentes aumentou a tensão entre eles no interior das unidades, que se viam como partes compartimentadas que se ameaçavam mutuamente. Os períodos após as trocas de governo ou de secretários de estado, com potenciais implicações na alteração da política socioeducativa e nas lógicas de demissões e contratações, parecem ter sido um terreno fértil para o aumento das tensões entre funcionários, com repercussões na administração disciplinar dos jovens internos, muitas vezes utilizada como recurso de pressão dos monitores contra a superintendência e coordenadores de unidades. Isso fica evidente em um depoimento de outro monitor que havia ingressado no sistema durante o governo Theotônio Vilela Filho:

“Depois de 7 meses que o projeto [de implantação do educador social] estava funcionando dentro das unidades começou a ter problemas entre o educador e o agente de segurança [monitor]. Os educadores começaram a entrar aos poucos. Não entraram em todas as unidades ao mesmo tempo. A intenção do secretário era tirar os agentes de segurança violentos, deixar o mínimo, só para fazer a segurança, e os educadores tomarem a frente de tudo, inclusive para acabar com a violência, pra acabar com qualquer coisa que tivesse viciado dentro do sistema. O educador fazia todo o serviço que o monitor faz hoje. O educador pagava o almoço, acompanhava a enfermeira na medicação, fazia listagem de quem queria falar com as técnicas. Os educadores acompanhavam eles do alojamento até as técnicas. Os educadores acompanhavam eles durante o almoço, no refeitório. Cada equipe tinha em torno de seis a sete educadores sociais. Foram dispensados muitos agentes de segurança. Em 2012 começou o problema. Os agentes começaram a boicotar o serviço do educador, com medo de perder o emprego. O educador já entrou recebendo mais do que os agentes em termos de salário. Na época, o agente de segurança recebia 640 reais e o educador era pra entrar com 1000 [reais]. Só que a política se mete no assunto e o educador acabou ganhando 740 [reais], mas foi suficiente para gerar o problema. Como eles já chegaram dizendo que queriam aumentar o salário do educador e o salário do monitor já estava a dois anos defasado então eles começaram a cruzar os braços e não estavam querendo nem fazer o serviço de segurança deles. Quando o projeto chegou na UIM, colocaram 
o coordenador dos educadores sociais como gerente da unidade. O superintendente o colocou como gerente, que era o projeto do secretário tirar os agentes penitenciários de dentro das unidades do sistema de menores e começar a colocar educadores que foram selecionados todos com nível superior. Eram educadores mas que eram psicólogos, assistentes sociais, educador físico, estudante de direito. As pessoas capacitadas como educadores não eram de nível médio, eram de nível superior. Só que os próprios agentes criaram uma situação pra tirar ele. Então eles incentivaram os adolescentes a fazer rebelião, pra poder botar fogo na unidade toda, pra não aceitar ele como gerente, pois sabiam que ele não tinha experiência na área de segurança. Um ótimo educador mas não era um agente penitenciário. Então, como chamam, fizeram uma "cocó", um "arrumadinho" pra ele. Aí ele perdeu o cargo de gerente dele. E ele ficou tão revoltado com o acontecido que ele saiu do sistema. Esse acontecimento da UIM foi o estopim da confusão. Quando essa confusão começou aí já se sabia que o projeto de educador social ia acabar porque o secretário não segurou. Pareceu um dominó caindo. O sistema antigo derrubou o novo. Os gerentes eram do sistema de adultos, eles não queriam perder o cargo comissionado deles e os monitores não queriam perder o emprego deles. $\mathrm{O}$ educador tava tirando aquele monitor que batia, aquele leão de chácara que tava tratando o adolescente com violência. Eles estavam sendo localizados e estavam saindo da unidade".

(Depoimento do monitor " $c$ " ao pesquisador).

O depoimento é revelador do tipo de equilíbrio de poder existente entre os funcionários do sistema socioeducativo vinculados às medidas de internação na qual estavam, e em grande medida ainda estão, a raiz da instabilidade do processo de padronização das práticas disciplinares dos monitores sobre os jovens e da direção institucional do sistema socioeducativo. Um equilíbrio tenso entre agentes que acreditam na violência como meio pacificador contra aqueles que professam a crença na possibilidade de disciplina sem violência física. Ambos os segmentos, entretanto, estão pressionados pela lógica de poder da negociação de mercadorias políticas, tal como Misse tem destacado os mecanismos de seu funcionamento (MISSE, 2010). Isso é importante para não idealizarmos simplificadamente a posição social dos agentes que fazem parte do sistema a partir apenas de sua crença disciplinar. Pode-se notar que, tal como em um determinado período do governo Ronaldo Lessa, tentou-se implementar em um determinado período do governo Theotônio Vilela Filho uma 
padronização das ações de disciplinamento dos jovens no interior das unidades numa direção de treinamento do funcionário estatal sob a égide de um ethos do educador social, em oposição às práticas associadas a um ethos de agente penitenciário. É curioso notar que dentro de um mesmo governo deu-se uma alteração na balança de poder que passou a pender para o lado dos crentes na disciplina penitenciária, com a superintendência de um mesmo secretário, que se viu obrigado a ceder aos funcionários do sistema carcerário que estavam administrando o núcleo socioeducativo. Esse equilíbrio de poderes pendente para o lado dos agentes do sistema penitenciário perdurou durante dois anos, quando, no final de 2014, após visitas do $\mathrm{CNJ}$, e tendo conhecido uma intensificação sem precedentes do processo de encarceramento, o sistema de internação conhece a bancarrota. Com fugas em massa e depredação de vários prédios do sistema, o juizado da infância e juventude decide pela intervenção, no final de 2014, proibindo novos encarceramentos, gerando a necessidade de improvisação de um novo espaço para o funcionamento de diferentes unidades. Ademais, a superintendência socioeducativa é mudada de secretaria no final do governo Theotônio Vilela Filho, indo para a Defesa Social, sob administração do sistema penitenciário. A superintendência das unidades de internação ficou sob essa arquitetura institucional entre janeiro e setembro de 2015, até que, já depois de iniciado o governo Renan Filho, há uma nova reformulação das diretrizes do sistema socioeducativo. As principais foram a substituição da secretaria responsável pelo sistema, agora subordinada à recém-criada SEPREV, um desdobramento da antiga SEPAZ, e da superintendência, anteriormente composta por agentes do sistema penitenciário, que passou às mãos de uma psicóloga, assessorada também por um psicólogo, oriundo da equipe de consultores em segurança pública da Fundação João Pinheiro e do CRISP da UFMG.

As reformas que começaram a ser implementadas a partir de setembro de 2015 são enunciadas como tendo por finalidade implementar uma direção de treinamento de monitores sob a concepção de práticas socioeducadoras. Mais uma vez, muda-se a direção da administração do sistema socioeducativo de Alagoas rumo ao polo oposto em relação ao qual vinham sendo gerenciadas as unidades. De diferentes agentes, ouvi afirmações - algumas receosas outras mais entusiastas - de que o Ministério Público e o Juizado da Infância e do Adolescente estavam fazendo esforços para investigar atos de violência física cometidos por alguns monitores, visando retirá-los do sistema. É bem possível que com o aumento dos 
temores de parte dos monitores sobre seus empregos e situações jurídicas, aumente-se a tensão no interior das unidades, fazendo com que a maneira de lidar com essa tensão seja um aspecto decisivo dos rumos subsequentes do sistema, altamente dependente dos monitores.

\section{Conclusão}

Estudos sobre as práticas disciplinares no interior das unidades de internação são crescentes (OLIC, 2009; MALLART, 2014) ainda que mais rara sejam as pesquisas sobre direções de padronização social de tais práticas numa escala mais ampla de tempo. $\mathrm{O}$ foco em percursos de maior duração poderia ajudar a observar tanto transformações intergeracionais quanto lógicas sociais de agressividades que se reproduzem, algumas expressando redução das distâncias e conflitos entre monitores e jovens, outras indicando suas intensificações, repercutindo em experiências de sofrimento e gratificação para ambos os setores que costumam assumir a feição de rebeliões e crises de violências súbitas publicitadas em notícias de jornais, rádios e TV's.

Um dos aspectos tratados no artigo é o fato de as ambivalências de concepções disciplinares no interior do sistema de internação alagoano terem se tornado um ponto de instabilidade entre superintendências, educadores e monitores ao longo de quase quatro décadas, culminando, nas décadas de 2000 e 2010, com diferentes ciclos de rebeliões, fugas e depredações dos edifícios do "sistema". Ao construir um esboço dessas tendências de oscilação entre sensos disciplinares incorporados nas práticas de monitores e fiscais ao longo desse período, indica-se que as dinâmicas de agressividades transmitidas nas relações abrigadas sob o "sistema" mantêm relações com alguns movimentos mais abrangentes da sociedade alagoana, especialmente os relacionados com as lutas entre grupos sociais pela concentração do poder de violência física no estado, particularmente membros da polícia, do sistema penitenciário, do judiciário e do Ministério Público. Sugerimos que as oscilações não são cíclicas; elas, a cada novo movimento pendular - entre os polos do educador social e do agente penitenciário - baseiam-se em um novo estágio da configuração da distribuição de poder de uso da força armada e simbólica que, como indicam as recentes taxas de letalidade policial, de encarceramento juvenil e de processamento de jovens em varas da infância e juventude, apontam para novas dinâmicas de transmissão social da agressividade, a requerer 
uma análise mais atenta sobre o significado das dinâmicas de refreamento de impulsos letais expressas nesses movimentos. Até onde consigo alcançar com as informações da pesquisa, o aumento dos conflitos entre jovens e monitores relacionados ao aumento do encarceramento juvenil e ao aumento da incriminação policial de jovens está relacionado com uma relativa redução das distâncias sociais de caráter econômico e de sensos de dignidade entre jovens de periferia e grupos mais próximos do financiamento estatal, possibilitada pela expansão dos mercados ilícitos e de redes de proteção estatal em Alagoas, algo recente. Ambivalentemente, entretanto, parece que Alagoas conhece um processo de aumento relativo da centralização do poder do uso da força em torno de grupos ligados a corporações policiais, sem que haja uma expropriação elevada do acesso a armas por grupos que buscam oportunidades de poder econômico, honra e valor humano em mercados ilícitos em "periferias urbanas". Tal situação parece apontar para uma longevidade de tradições de agressividade envoltas por linguagens militares de superioridade humana, criando grandes constrangimentos para a expansão de um tipo de cultura disciplinar civil-democrática, na qual as agressividades decorrentes da busca por reconhecimento e valor humano sejam canalizadas para camadas de linguagens reivindicatórias sob a forma de diálogo e de gestos de criação de imagens-denós mais abarcantes, tanto entre aqueles que detêm o poder de disciplinar quanto entre aqueles que acabam por ocupar a posição de serem disciplinados. Os receios mútuos retroalimentam as potencialidades para a violência física em uma cadeia que parece interminável.

Um dos problemas fundamentais a serem enfrentados, portanto, é a relação entre as linguagens de agressividade disponíveis na cadeia intergeracional do sistema e da sociedade alagoana, de maneira mais abrangente. O curso do sistema, em grande medida, está ancorado nas relações monitor-socioeducando, e o foco apenas em um desses polos isoladamente ainda não nos dirá o suficiente sobre alternativas concretas de buscas civilizatórias para propostas de reeducação.

\section{Referências}

ALVAREZ, Marcos César; SALLA, Fernando; DIAS, Camila Nunes.

(2013). Das Comissões de Solidariedade ao Primeiro Comando da Capital em São Paulo. Tempo Social, v. 25, n. 1, p. 61-82.
BRASIL.

(1976). Resolução n 21, de 23 de junho de 1976. Aprova o Relatório e as Conclusões da Comissão Parlamentar de Inquérito destinada a investigar o problema da Criança e do Menor carentes do Brasil. Diário do Congresso Nacional, DF, 29 de junho. 
CARVALH0, Cícero Péricles de.

(2015). Formação histórica de Alagoas. Maceió, Edufal.

DRYBREAD, Kryten.

(2014). Murder and the Making of Man-Subjects in a Brazilian Juvenile Prison. American Anthropologist, v. 116, n. 4, p. 752-764.

ELIAS, Norbert.

(1978). On Transformations of Aggressiveness. Theory and Society, Vol. 5, No. 2, pp. 229242. Springer. Disponivel em: http://www. jstor.org/stable/656698. Acesso em 22 de setembro de 2012.

(2002). Teoria simbólica. Oeiras, Celta Editora.

FELTRAN, Gabriel de Santis.

(2010). Crime e Castigo na cidade: os repertórios da justiça e a questão do homicídio nas periferias de São Paulo. Cadernos CRH, JanAbr, p. 59-73.

PORTAL DE NOTÍCIAS G1 - GRUPO GLOBO.

(2013). Sistema socioeducativo de AL está um absoluto caos, diz juiz. CNJ. G1. Disponível em: <http://g1.globo.com/al/alagoas/ noticia/2013/09/sistema-socioeducativo-deal-esta-um-absoluto-caos-diz-juiz-no-cnj. html>. Acesso em 07 de junho de 2015.

\section{GAZETA DE ALAGOAS - ORGANIZAÇÕES ARNON DE MELLO.}

(2015). Unidades de internação registraram fuga de 142 jovens no último ano. Gazetaweb, Disponivel em: <http://gazetaweb.globo. com/noticia. php? $\mathrm{c}=393379 \& \mathrm{e}=6>$. Acesso em: 07 jun. 2015.

(2014) Unidade de internação é interditada após fuga de menores. Gazetaweb. Disponível em: <http://gazetaweb.globo.com/ gazetadealagoas/noticia.php?c=257125>. Acesso em: 05 jun. 2015.

(2014a). Em meio a impasse, Juiz da Infância determina que Uija seja lacrada. Gazetaweb. com, Disponivel em: <https://www.google. com.br/url? sa $=t \& r c t=j \& q=\&$ esrc $=s \&$ sourc $e=w e b \& c d=1 \& c a d=r j a \& u a c t=8 \& v e d=0 C B$ 0QFjAA\&url=http $\% 3 A \% 2 F \% 2 F g a z e t a w e b$. globo.com\%2Fnoticia.php\%3Fc\%3D3712 $74 \% 26$ e\%3D13\&ei=fQ50VeWBEMacNsP5g
tAH\&usg=AFQjCNEadHdtec8DPm $2 \mathrm{mBr} 7$ qwPvCwIRag \&bvm =bv.95039771, d.eXY>. Acesso em 05 de junho de 2015.

(2014b). Menores usam cerca de arame e fogem de unidade de internação. Gazetaweb.com, Disponivel em: <http://gazetaweb.globo. com/noticia.php? $c=376629 \& \mathrm{e}=13>$. Acesso em 06 de junho de 2015.

(2014c). Após assassinato na UIM, juiz da Infância defende intervenção federal. Gazetaweb.com, Disponivel em: <http://gazetaweb.globo.com/noticia. php?c=367125\&e=13>. Acesso em 07 junho de 2015.

(2013). Adolescente é estrangulado em Unidade de Internação de Menores. Gazetaweb.com, Disponivel em: <http://gazetaweb.globo. com/noticia.php? $c=345377 \& \mathrm{e}=12>$. Acesso em 06 junho de 2015.

LIMA, Araken Alves de.

(1998). A crise que vem do verde da cana: uma interpretação da crise financeira do estado de Alagoas no período 1988-96. Maceió, EDUFAL.

LOPREAT0, Francisco Luiz Cazeiro.

(2002). 0 colapso das finanças estaduais $e$ a crise da federação. São Paulo, Editora Unesp / IE Unicamp.

MAJELLA, Geraldo de.

(2006). Execuções sumárias e grupos de extermínio em Alagoas (1975-1998). Maceió, Edufal.

MALLART, Fábio.

(2011). Salve geral: áreas urbanas, instituições prisionais e unidades de internação da Fundação CASA em comunicação. Revista de Antropologia Social dos Alunos do PPGASUFSCar, v.3, n.1, jan.-jun., p.293-314.

MALTA, Cláudia Viana de Melo.

(2009). A (in)visibilidade de crianças e adolescentes. Maceió, Edufal.

MALTA, Cláudia Viana de Melo; VERAS, Mariluce de Macedo.

(1998) Caracterização da criança e do adolescente no município de Maceió. Maceió, Edufal. 
SECRETARIA-GERAL DA PRESIDÊNCIA DA REPÚBLICA E SECRETARIA NACIONAL DE JUVENTUDE.

(2015) Mapa do Encarceramento: os jovens do Brasil. Brasília, Presidência da República.

MENNELL, Stephen.

(2007). The american civilizing process. Cambridge, Polity.

MISSE, Michel.

(2011). Crime e Violência no Brasil Contemporâneo. Rio de Janeiro: Lumen Juris.

(2010). Crime, sujeito e sujeição criminal: aspectos de uma contribuição analítica da categoria bandido. São Paulo, Lua Nova. p.15-38.

(2008). Acusados \& acusadores: estudos sobre ofensas, acusações e incriminações. Rio de Janeiro, Revan.

(2007). Notas sobre a sujeição criminal de crianças e adolescentes. In: Vanilda Paiva; João Trajano de Sento-se (Orgs.); Jovens em conflito com a lei. Rio de Janeiro, Garamond.

OLIC, Maurício Bacic.

(2009). A casa está na mão de quem? Hierarquia e relações de poder no interior de Unidades de Internação destinadas a jovens infratores. Cadernos de Campo, n. 18, p. 107-125.

POTENGY, Gisélia.

(2007). A descentralização do atendimento de jovens em conflito com a lei no Rio de Janeiro. In: Vanilda Paiva; João Trajano de Sento-Sé (Orgs.); Jovens em conflito com a lei. Rio de Janeiro, Garamond.

SALLA, Fernando.

(2006). As rebeliões nas prisões: novos significados a partir da experiência brasileira. Sociologias, jul/dez 2006, p. 274-307 v. 8, n. 16.

SANTOS, Fernando Antônio Agra.

(1999). Crédito rural e produtividade na agricultura alagoana - 1973-94. Maceió, Edufal.
SANTOS, Liane Pessin dos; FREITAS, Lia Beatriz de Lucas.

(1989). Na Febem éassim? A gente só aprende na porrada?. Psicologia: ciência e profissão, 09. Disponivel em: <http://www.scielo.br/scielo. php?script=sci_arttext\&pid=S1414-98>. Acesso em 06 de junho de 2015.

SPIERENBURG, Pieter.

(1987). From Amsterdam to Auburn: an explanation for the rise of the prison in seventeenth-century Holland and nineteenth-century America. Journal of Social History, 20 (3), p. 439-462.

TILLY, Charles.

(1969). Collective violence in european perspective. In: Hugh Davis Graham; Ted Robert Gurr. The history of violence in America. New York, Frederick A. Praeger / Inc Publishers.

WINNICOT. Donald.

(2005). Privação e delinquência. São Paulo, Martins Fontes.

ZALUAR, A.

(2012). Juventude Violenta: Processos, Retrocessos e Novos Percursos. Dados, 327365.

\section{Recebido em}

março de 2016

\section{Aprovado em}

maio de 2017 